\title{
Hydrothermal synthesis of bacterial cellulose-copper oxide nanocomposites and evaluation of their antimicrobial activity
}

\author{
Inês M.S. Araújo ${ }^{a}$, Robson R. Silva ${ }^{\mathrm{b}, \mathrm{f}}$, Guilherme Pacheco ${ }^{\mathrm{c}}$, Wilton R. Lustri ${ }^{\mathrm{c}}$, Agnieszka Tercjak ${ }^{\mathrm{d}}$, \\ Junkal Gutierrez ${ }^{\mathrm{d}}$, José R.S. Júnior ${ }^{\mathrm{a}}$, Francisco H.C. Azevedo ${ }^{\mathrm{e}}$, Girlene S. Figuêredo ${ }^{\mathrm{a}}$, \\ Maria L. Vega ${ }^{\mathrm{a}}$, Sidney J.L. Ribeiro ${ }^{\mathrm{b}}$, Hernane S. Barud ${ }^{\mathrm{c}, *}$ \\ ${ }^{a}$ Universidade Federal do Piauí, Departamento de Química, Campus Ministro Petrônio Portela, Uninga, 64049-550,Teresina, PI, Brazil \\ b Universidade Estadual Paulista Júlio de Mesquita Filho, Instituto de Química de Araraquara, Departamento de Química Geral e Inorgânica, Rua Professor Francisco \\ Degni, 55, Jardim Quitandinha, 14.800-060, Araraquara, SP, Brazil \\ c Universidade de Araraquara, Uniara, Laboratório de Biopolímeros e Biomateriais (BIOPOLMAT), Rua. Carlos Gomes, 1217, 14.801-320, Araraquara, SP, Brazil \\ ${ }^{\mathrm{d}}$ University of the Basque Country (UPV/EHU), Dpto. Ingeniería Química y del Medio Ambiente, Escuela Politécnica Donostia-San Sebastián, Pza. Europa 1, 20018, \\ Donostia-San Sebastián, Spain \\ e Universidade Luterana do Brasil, Programa de Pós Graduação Em Genética e Toxicologia Aplicada, Av. Farroupilha, 8001, Prédio 01, São Luís, 92.450-900, Canoas, \\ RS, Brazil \\ ${ }^{\mathrm{f}}$ Instituto de Física de São Carlos, Universidade São Paulo, 13560-970, São Carlos, SP, Brazil.
}

\section{A R T I C L E I N F O}

\section{Keywords:}

Bacterial cellulose

Hydrothermal synthesis

Copper nanoparticles

\begin{abstract}
A B S T R A C T
In this work, for the first time bacterial cellulose (BC) hydrogel membranes were used for the fabrication of antimicrobial cellulosic nanocomposites by hydrothermal deposition of $\mathrm{Cu}$ derivative nanoparticles (i.e.Cu(0) and CuxOy species). BC-Cu nanocomposites were characterized by FTIR, SEM, AFM, XRD and TGA, to study the effect of hydrothermal processing time on the final physicochemical properties of final products. XRD result show that depending on heating time (3-48 h), different CuxOy phases were achieved. SEM and AFM analyses unveil the presence of the $\mathrm{Cu}(0)$ and copper CuxOy nanoparticles over BC fibrils while the surface of 3D network became more compact and smother for longer heating times. Furthermore, the increase of heating time placed deleterious effect on the structure of BC network leading to decrease of BC crystallinity as well as of the on-set degradation temperature. Notwithstanding, BC-Cu nanocomposites showed excellent antimicrobial activity against $E$. coli, $S$. aureus and Salmonella bacteria suggesting potential applications as bactericidal films.
\end{abstract}

\section{Introduction}

Cellulose is the most abundant polysaccharide in nature (Czaja, Romanovicz \& Brown, 2004; Domini et al., 2010; Esa, Tasirin \& Rahman, 2014; Thakur \& Voicu， 2016 Fu， Zhang \& Yang, 2013) and the major structural components of the plant cell walls (Tsouko et al., 2015). Cellulose is composed by D-glucose monomeric units linked by $\beta-(1 \rightarrow 4)$ glycosidic bonds and the extended intra and inter-molecular hydrogen bonds among the subunits are responsible for its water insolubility. However, algae and some types of prokaryotic organisms, such as cyanobacteria (Czaja et al., 2004), have also the ability to produce this polymer.

Bacterial cellulose (BC) is a biosynthesized cellulose produced by culturing a strain of aerobic Gram-positive bacteria from the genres Gluconacetobacter, Rhizobium, Sarcina, Agrobacterium, Alcaligenes, Aerobacter, Azotobacter and Salmonella (Iguchi, Yamanaka \& Budhino, 2000; Jipa et al., 2012). To date, Gluconacetobacter is the highest yield BC-producing strain (Castro et al., 2013; Domini et al., 2010; Rajwade, Paknikar \& Kumbhar, 2015).

Although the structural formula of BC is identical to vegetable cellulose, it shows a high degree of purity being free of lignin and hemicellulose. In addition, BC has high mechanical stability, high crystallinity (70-80\%), high degree of polymerization and excellent water retention capacity. BC fibers are about 100 times thinner than plant cellulose (i.e. scale downs to nanoscale range), making them a highly porous biomaterial. Furthermore, the $\mathrm{BC}$ is a biodegradable,

\footnotetext{
* Corresponding author.

E-mail addresses: ines.maria.chemistry.ufpi@gmail.com (I.M.S. Araújo), robsilva31@gmail.com (R.R. Silva), guilhermepacheco85@hotmail.com (G. Pacheco), wrlustri@yahoo.com.br (W.R. Lustri), agnieszka.tercjaks@ehu.es (A. Tercjak), juncal.gutierrez@ehu.es (J. Gutierrez), jribeiro@ufpi.edu.br (J.R.S. Júnior), honeidy@gmail.com (F.H.C. Azevedo), girlenesf@gmail.com (G.S. Figuêredo), marialeticia.vega@gmail.com (M.L. Vega), sjlribeiro@gmail.com (S.J.L. Ribeiro), hernane.barud@gmail.com (H.S. Barud).
} 


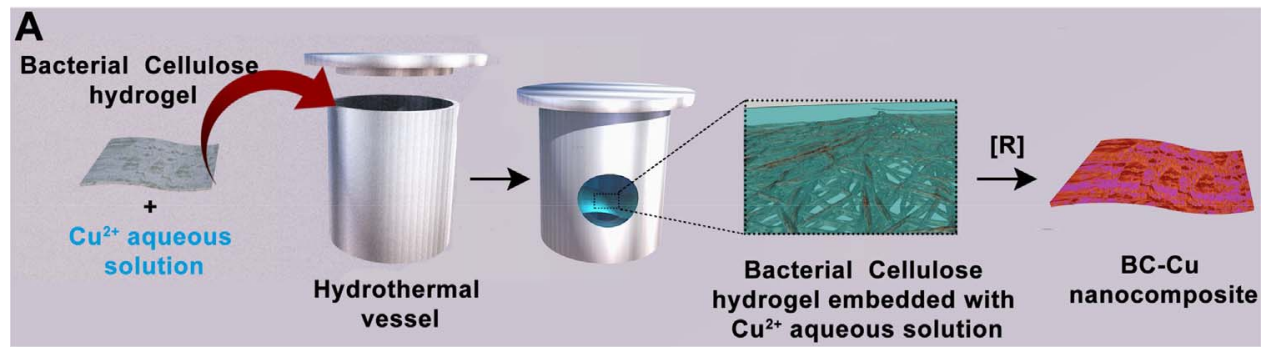

B

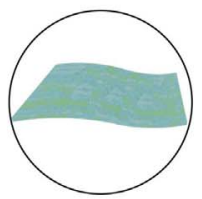
$\mathrm{Cu}^{2+}$ aqueous solution
aquel embedded with

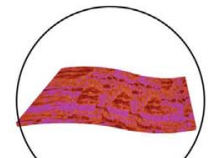

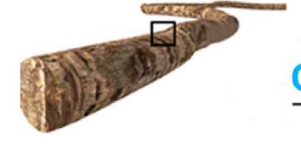
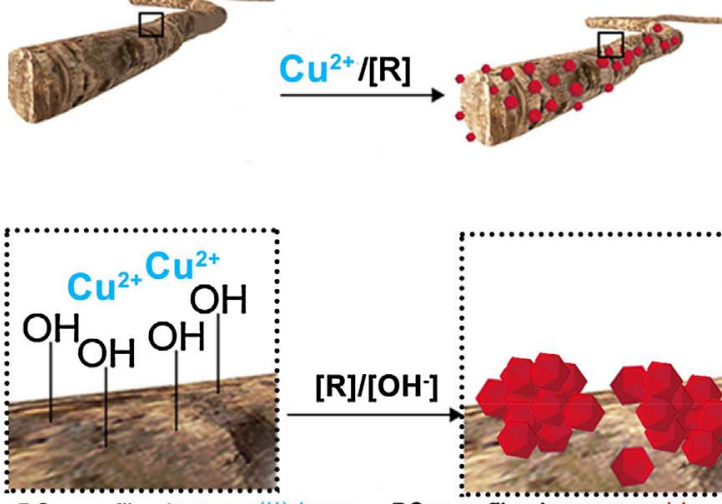

BC nanofiber/copper(II) ions

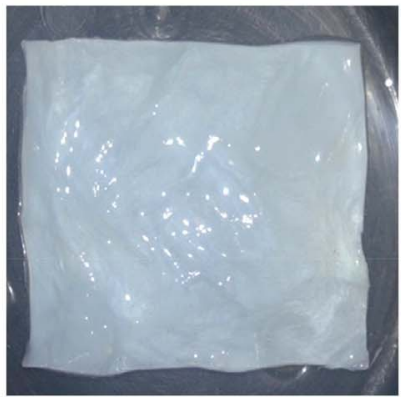

nanofiber/copper oxide
Fig. 1. (A and B) Representative scheme of $\mathrm{Cu}$ deposition into BC membrane surface using hydrothermal synthesis of BC-Cu nanocomposite. On the bottom, picture of pristine $\mathrm{BC}$ never-dried membranes and, BC-Cu nanocomposites prepared after hydrothermal condition. The hydrothermal condition concerns to subject the $\mathrm{BC}$ hydrogel immersed in $\mathrm{Cu}(\mathrm{II})$ aqueous solution at temperature of $150{ }^{\circ} \mathrm{C}$ during $3 \mathrm{~h}$. BC-Cu membrane showed a blackish color as effect of the reduction of $\mathrm{Cu}$ (II) to CuNPs (i.e. $\mathrm{Cu}(0)$ or $\mathrm{CuxOy}$ nanoparticles).
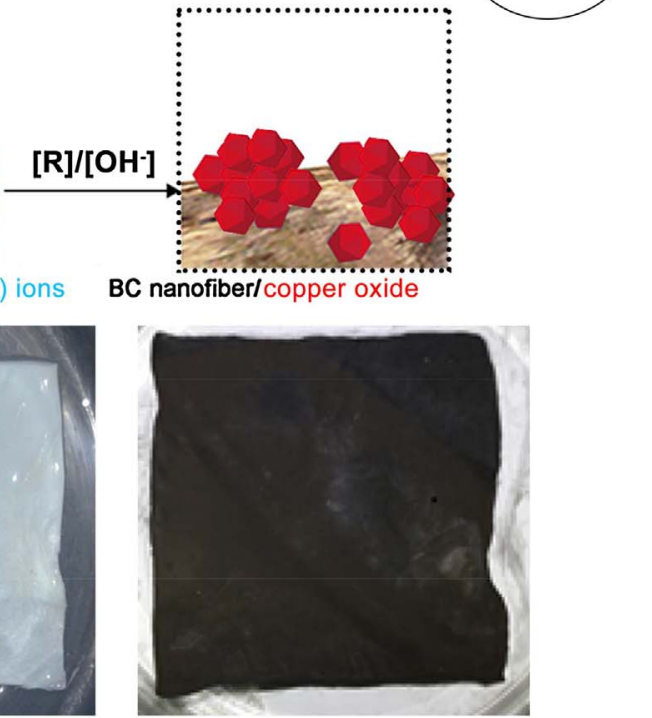

biocompatible, non-toxic and non-allergenic polymer (Barud et al., 2013; Barud et al., 2016; Czaja et al., 2004; Czaja, Krystynowicz, Bielecki, \& Brown, 2006; Domini et al., 2010; Kiziltas, Kiziltas, Blumentritt \& Gardner, 2015; Iguchi et al., 2000; Jipa et al., 2012; Lin \& Dufresne, 2014; Lin et al., 2013; Pineda, Mesa \& Riasco, 2012; Nishiyama, 2009; Tsouko et al., 2015; Wang et al., 2011; Wang, Lu \& Zhang, 2016; Yang, Xiaoli, Liyong, \& Dongping, 2013). BC has been intensively studied in cosmetics, textile, food, paper and medical fields (surgical implants, scaffolds, cartilage and meniscus implants, cardiovascular implants, treatment of chronic wounds, stents coating and bone regeneration material) (Andrade, Costa, Domingues, Soares \& Gama, 2010; Bodin et al., 2010; Cavka et al., 2013; Domini et al., 2010; Gao et al., 2011; Keshk, 2014; Kowalska-Ludwicka et al., 2013; Lopes et al., 2011; Lin et al., 2013 Martínez, Brackmann, Enejder \& Gatenholm, 2012; Svensson et al., 2005; Woehl et al., 2010; Wei, Yanga \& Honga, 2011; Yang, Xie, Hong, Cao, \& Yang, 2012; Yang, Chen, \& Wang, 2014). For instance, it has been used in technological applications such as audio devices, fuel cell membranes, electronic paper, transparent optical nanocomposites, drug-releasing systems, vascular grafts, and supports for in vitro and in vivo tissue engineering (Czaja et al., 2006; Trovatti et al., 2012; Wei et al., 2011).

BC fiber surface accounts to an abundant site rich in hydroxyl groups, whose feature enables the adsorption of metal ions or metallic nanoparticles (Kiziltas et al., 2015; Pinto, Marques, Martins, Neto, \& Trindade, 2007). Recently, BC has been engineered as a support for inorganic nanoparticles possessing antimicrobial activity such as $\mathrm{Ag}$ and $\mathrm{Cu}$ (Barud et al., 2011; Cady, Behnke, \& Strickland, (2011), Pinto et al., 2007; Chen et al., 2013; Hu, Chen, Zhou \& Waing, 2010; Jiazhi, Xiaoli, Liyong \& Dongping, 2013; Jiazhi et al., 2013; Pinto, Neves, Neto, \& Trindade, 2012; Song, Birbach \& Hinestroza, 2012; Maneerung, Tokura \& Rujiravanit, 2008; Yang et al., 2012).

Pinto et al. evaluated the growth and chemical stability of $\mathrm{Cu}$ nanoparticles using bacterial and vegetal cellulose as matrixes. According to the the authors BC was more efficient matrix to avoid copper surface oxidation. (Pinto et al., 2007)

Cady et al. have investigated the synthesis of cellulose copper nanoparticles by an electrostatic assembly process. The obtained cellulose-copper composites displayed antimicrobial effect against resistant pathogen A. baumannii (Cady et al., 2011Cady et al., 2011). Several works also show the use of cellulose as reducing matrix to prepare cellulose-copper composites. Vainio et al. studied the preparation of cellulose-copper composites by self-supporting $\mathrm{Cu}$ ions onto microcrystalline cellulose (MC). MC has been acting as catalyst to reduce $\mathrm{Cu}$ in different reduced species such as $\mathrm{Cu}, \mathrm{CuO}$ and $\mathrm{Cu}_{2} \mathrm{O}$ (Vainio et al., 2007). Li et al. developed a green process using a hydrothermal method under high temperature conditions using cellulose as reducing agent. A reaction mechanism for the reduction of $\mathrm{CuO}$ to $\mathrm{Cu}$ using cellulose matrix was proposed (Li et al., 2012). Therefore, at this moment there are no reports related to use of bacterial cellulose as matrix to prepare $\mathrm{Cu}$ and $\mathrm{CuO}_{\mathrm{x}}$ species using hydrothermal synthesis.

Among several inorganic nanoparticles, copper stands out due to its antimicrobial properties against well-known pathogenic microorganisms, such as Salmonella typhimurium and Listeria monocytogenes (Ógorman \& Humphreys, 2012; Gould et al., 2009). Metallic copper and 


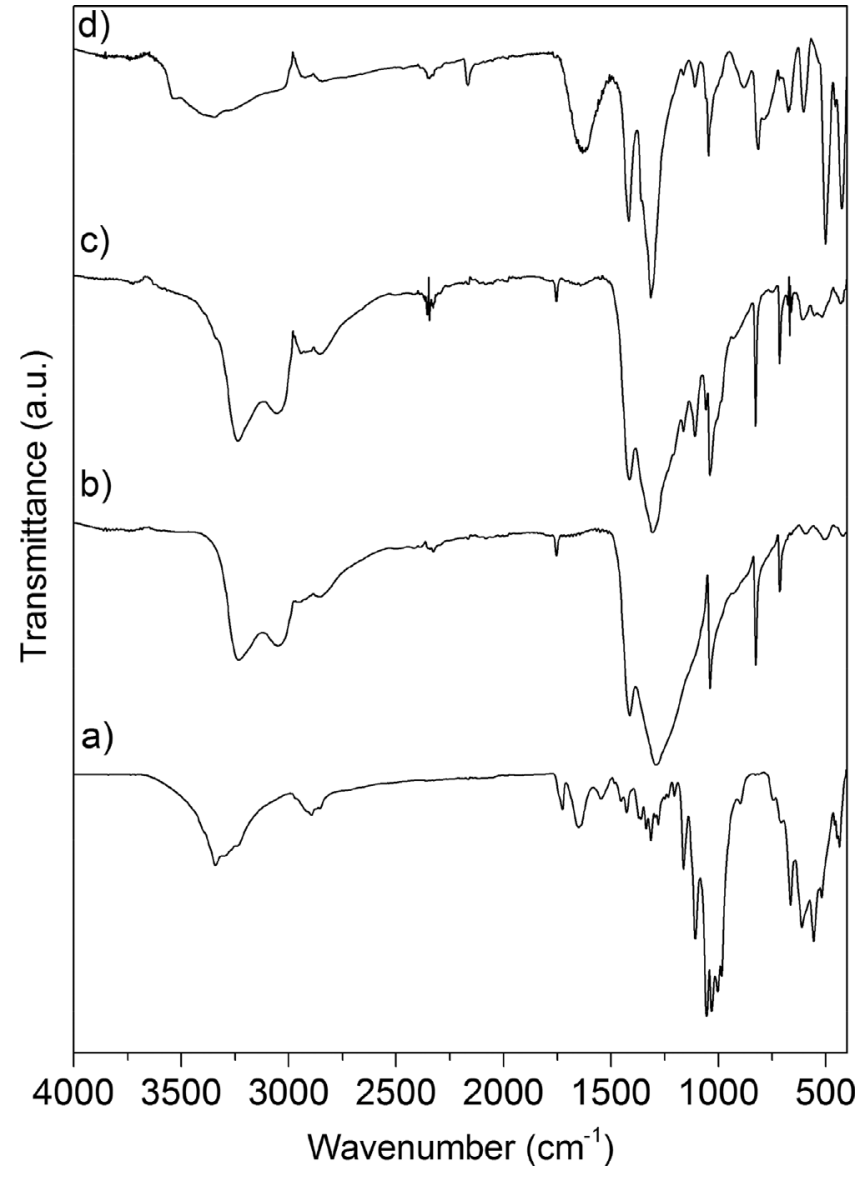

Fig. 2. FTIR spectra of pristine $B C$ membrane (a), and BC-Cu nanocomposites synthetized by hydrothermal synthesis during (b) $3 \mathrm{~h}$, (c) $24 \mathrm{~h}$ and (d) $48 \mathrm{~h}$.

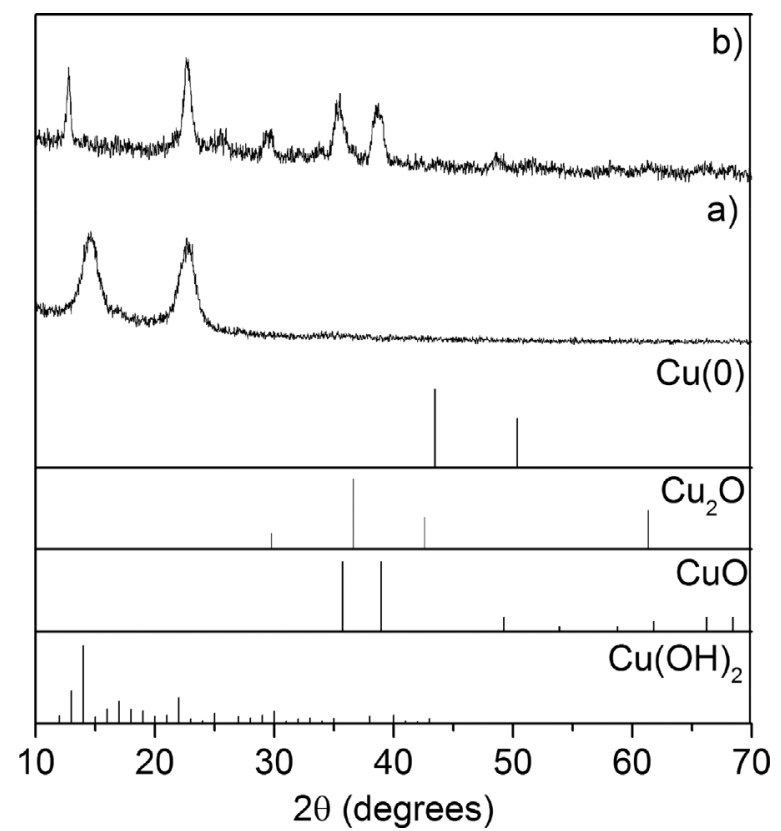

Fig. 3. X-ray diffraction for (a) dried BC membrane and (b) BC-Cu nanocomposites synthetized within $48 \mathrm{~h}$ under hydrothermal conditions.

copper alloys have also shown bactericidal activity against Salmonella enterica and Campylobacter jejuni (Zhu, Elguindi, Rensing, \& Ravishankar, 2012). Under sizes down nanometric range, copper particles display excellent antibacterial and catalytic activity, distinguished optical and magnetic properties than its bulk counterpart or similar sized gold, silver or palladium nanoparticles (Umer, Naveed, Ramzan, Rafique, Imran, 2014; Yao, Huo \& Jin, 2011).

$\mathrm{Cu}$ nanoparticles (CuNPs) can be obtained by using several physical methods such as pulsed laser ablation, vapor deposition, high-energy mechanical milling and even by chemical techniques like microemulsion, sonochemical or electrochemical reduction, assisted microwave and hydrothermal synthesis (Liu \& Bando, 2003; Ethiraj \& Kang, 2012; Umer et al., 2014). In this work, we highlight the synthesis of CuNPs under hydrothermal conditions, which enables to undertake homogeneous reaction of acidic or basic aqueous solutions inside sealed containers under controlled pressure and temperature (Rueff et al., 2016; Shouhua \& Xu, 2001; Shi, Song \& Zhang, 2013; Feng \& Xu, 2001).

The hydrothermal method has increasingly attracted attention due to its numerous advantages, especially due to simple, easy-to-handle experimental apparatus. The employment of the hydrothermal method allows to form more stable, condensed phases, achievement of high yield of outcome, as well as low energy consumption. The synthesis parameters such as temperature and time, $\mathrm{pH}$, concentration of precursor, among others, are fundamental keys to a successful preparation of high-quality nanostructures (Shi et al., 2013).

In this study, time-dependent chemical deposition of CuNps (i.e. $\mathrm{Cu}$ (0) or CuxOy nanoparticles) on the BC membranes was successfully controlled by the hydrothermal synthesis. BC-Cu nanocomposites were study to confirm presence of the CuNPs and their effect on the final properties. The antimicrobial activity of the resulting $\mathrm{BC}-\mathrm{Cu}$ nanocomposites was also evaluated.

\section{Experimental section}

\subsection{Materials and methods}

The BC membranes were prepared at the University of Araraquara (UNIARA). The Gluconacetobacter hansenii bacteria, ATCC 23769 strain, were grown in $30 \times 60 \mathrm{~cm}^{2}$ plates, with growing time of $96 \mathrm{~h}$ at $25^{\circ} \mathrm{C}$. The growth medium was composed by a homogeneous aqueous solution of $50 \mathrm{~g}$ of D-glucose and $4 \mathrm{~g}$ of yeast extract dissolved in $1000 \mathrm{~mL}$ of distilled water. After the growth media had been sterilized, $20 \mathrm{~mL}$ of ethyl alcohol were added to it. The highly hydrated BC membranes, with average thickness in millimeter range were obtained. Then, the membranes underwent a purification stage, with a solution of $0.1 \mathrm{M}$ $\mathrm{NaOH}$ at $70{ }^{\circ} \mathrm{C}$ for $45 \mathrm{~min}$, for removing bacteria that could possibly exist. After that, $\mathrm{BC}$ membrane was washed with distilled water and stored by immersing in water solution at $5{ }^{\circ} \mathrm{C}$.

\subsection{Synthesis of BC-Cu nanocomposite}

Never-dried BC membrane $(5 \mathrm{~cm} \times 5 \mathrm{~cm})$ was placed in PTFE cup, with capacity of $30 \mathrm{~mL}$ and then $25 \mathrm{~mL}$ of copper nitrate solution, $\mathrm{Cu}$ $\left(\mathrm{NO}_{3}\right)_{2}, 0.05 \mathrm{~mol} \mathrm{~L}^{-1}$ was added. The mixture was stirred for $1 \mathrm{~h}$. Afterwards, $1 \mathrm{~mL}$ of $0.5 \mathrm{~mol} \mathrm{~L}^{-1}$ solution of $\mathrm{NH}_{4} \mathrm{OH}$ was added to this mixture. The cup was introduced inside a steel stainless reactor and sealed. After that, the reactor was heated in an oven previously set to $150{ }^{\circ} \mathrm{C}$. The thermal treatment was done for different heating times: 3 , 6,24 and $48 \mathrm{~h}$. After the hydrothermal synthesis, the product was characterized by different morphological, thermal and spectroscopic techniques.

\subsection{Characterization}

\subsubsection{Fourier transform infrared spectroscopy (FTIR)}

The Fourier Transform infrared spectra (FTIR) were performed using a Nicolet Nexus Spectra device, equipped with Golden Gate ATR Diamond. The spectra were registered with resolution of $2 \mathrm{~cm}^{-1}$ and average of 32 scans in the mid-infrared region $\left(4000-400 \mathrm{~cm}^{-1}\right)$. 

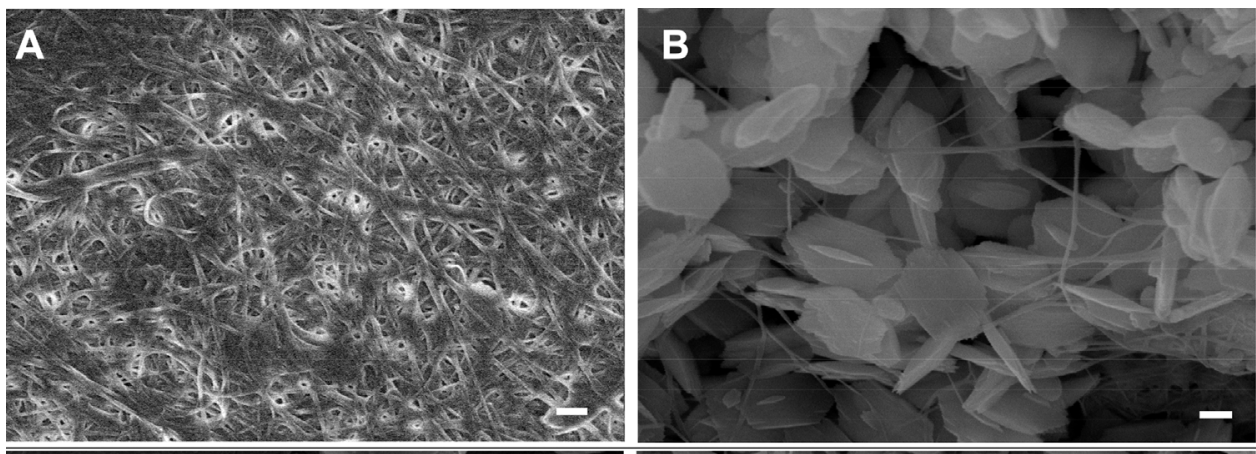

Fig. 4. SEM images of A) BC membrane and BC-Cu nanocomposites synthesized, B) $3 \mathrm{~h}, \mathrm{C)} 24$ and D) $48 \mathrm{~h}$.
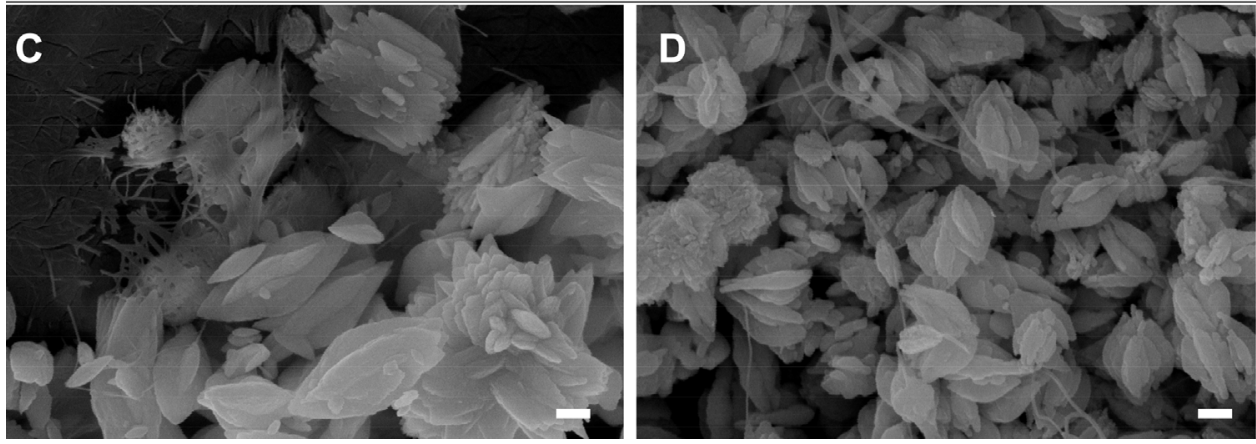

\subsubsection{Scanning electron microscope (SEM)}

The SEM measurement was carried out using a field-emission scanning electron microscope JEOL, model JSM-7000F, instrument operated at $2 \mathrm{kV}$. The investigated $\mathrm{BC}$ membrane and $\mathrm{BC}-\mathrm{Cu}$ nanocomposites were covered with carbon.

\subsection{3. $X$-ray diffractions (XRD)}

Dried BC membrane and BC-Cu nanocomposites, both pure and after hydrothermal synthesis, were submitted to XRD analysis. The XRD were performed using a SHIMADZU model D600-XR A equipment. The $\mathrm{Cu} \mathrm{K} \alpha \mathrm{X}$-ray source was set to $40 \mathrm{kV}$ and $100 \mathrm{~mA}$ and the investigated materials were examined over the angular range from $10^{\circ}$ to $30^{\circ}$ with the scanning speed of $8.33 \times 10^{-2} \mathrm{~s}^{-1}$.

\subsubsection{Thermogravimetric analysis (TGA)}

The TGA was performed using a thermogravimetric analyzer TAINSTRUMENT (SDT Q600 V20.9 Build 20), in an alumina crucible with approximately $5 \mathrm{mg}$ of each sample. The temperature varied between 25 and $600{ }^{\circ} \mathrm{C}$ with a heating rate of $10^{\circ} \mathrm{C} / \mathrm{min}$ in an oxidizing atmosphere (air).

\subsubsection{Atomic force microscopy (AFM)}

The surface of BC-Cu nanocomposites was analyzed by AFM operating in a tapping mode with a scanning probe microscope Dimension ICON from Bruker equipped with an integrated silicon tip/cantilever having a resonance frequency of $300 \mathrm{kHz}$. Scan rates ranged from 0.7 to $1.2 \mathrm{~Hz} \mathrm{~s}^{-1}$. In order to obtain repeatable results, different regions of the specimens were scanned to choose representative AFM images. Taking into account that obtained height and phase AFM images were very similar, only AFM phase images are shown.

\subsubsection{Study of the antimicrobial activity}

BC membranes modified with the HS were applied as antimicrobial films. The antimicrobial activities of $\mathrm{BC}-\mathrm{Cu}$ nanocomposite were analyzed in the presence of Gram-negative bacteria (Salmonella enterica) and Gram-positive (Staphylococcus aureus), and yeast (Candida albicans) using the disk diffusion method in agar. The analysis procedure consisted of the catting of BC-Cu nanocomposites in the shape of discs with $1 \mathrm{~cm}$ in diameter, and autoclaved them for $15 \mathrm{~min}$ at $120^{\circ} \mathrm{C}$. The bacteria strains were inoculated in tubes containing $2.0 \mathrm{~mL}$ of sterile BHI and incubated for $18 \mathrm{~h}$ at $37{ }^{\circ} \mathrm{C}$. Sufficient inoculum were added in new tubes containing $2.0 \mathrm{~mL}$ of sterile BHI broth until the turbidity equalled $0.5 \mathrm{McFarland}\left(\sim 1.5 \times 10^{8} \mathrm{CFU} \mathrm{mL}^{-1}\right)$. The bacterial inoculum diluted with BHI (McFarland standard) were uniformly spread using sterile cotton swabs on sterile Petri dishes containing MH agar. All BC$\mathrm{Cu}$ nanocomposite discs were placed on the surface of the solid agar inoculated with the bacterial and yeast. The plates were incubated for $18 \mathrm{~h}$ at $35-37^{\circ} \mathrm{C}$ and examined thereafter. Clear zones of inhibition around the discs were measured and the sensitivities of the complexes were assayed from the diameter of the inhibition zones (in millimetres). All the experiments were performed in triplicate. The diffusion inhibition zones for standard antibiotics can be found in CLSI (CLSI, 2016).

\section{Results and discussion}

\subsection{Hydrothermal synthesis}

The hydrothermal synthesis of BC-Cu nanocomposites was performed for different time reactions: $0,3,6,24$ and $48 \mathrm{~h}$. BC-Cu nanocomposites displayed different colors depending of the evaluated heating time: from bright white to dark brown, confirming CuNPs formation as shown in Fig. 1.

A detailed representative scheme of $\mathrm{Cu}$ deposition into $\mathrm{BC}$ membrane surface using hydrothermal process is shown in Fig. 1.

It is worth to pointing out that the $\mathrm{BC}$ membrane can undertake lateral reactions during the hydrothermal conditions. In order to strength our investigation over the mechanism of CuNPs deposition, a never-dried pristine $\mathrm{BC}$ membrane was subjected to the same hydrothermal conditions described in the experimental section, except that $\mathrm{Cu}(\mathrm{II})$ solution was replaced by water. Although the outcome resembles the original color of a regular BC hydrogel, the residual supernatant displayed a yellow-brownish color after $48 \mathrm{~h}$ heating time.

Supernatant was analyzed by complexometric titration with EDTA and the result for the presence of reducing sugars was positive. This could be an indicative of the preliminary occurrence of BC hydrolysis (releasing reducing sugars to the solution) under alkaline medium. Similar results were obtained by Bobleter (1994). This degradation process is mostly characterized by the loss of hydroxyl groups, by the cleavage of polymerization bonds and formation of structures derived from breakdown of glucose molecules in the structure also called 

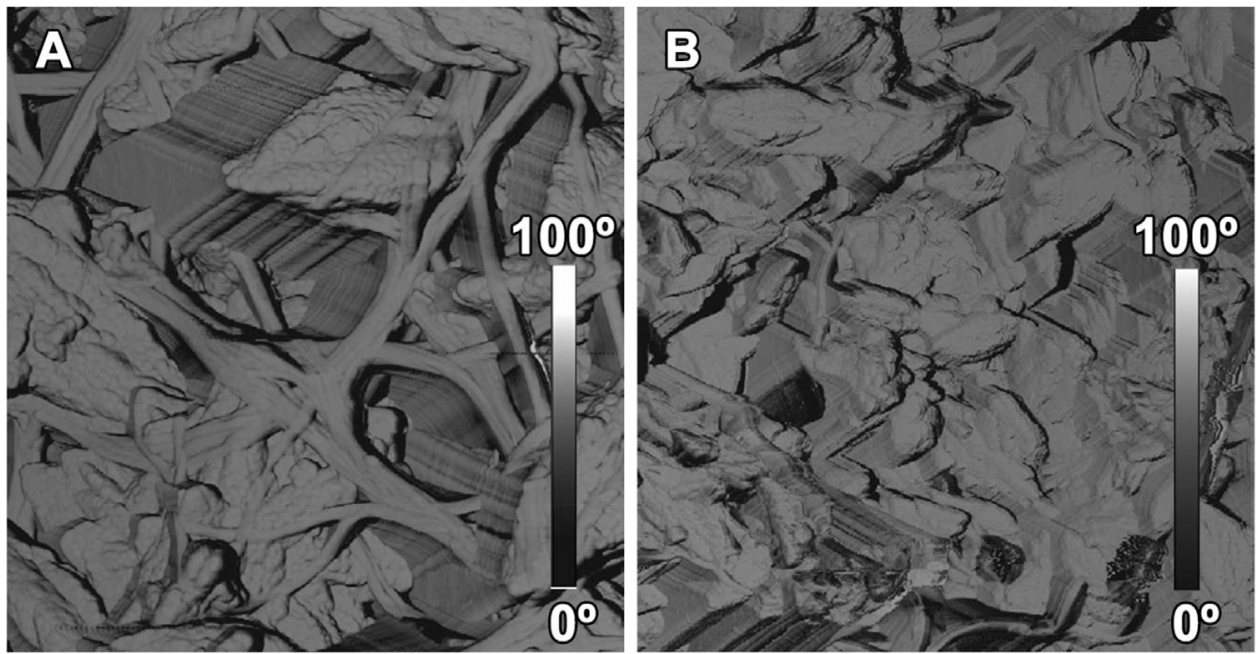

Fig. 5. AFM phase images of BC-Cu nanocomposites synthetized A) and B) $3 \mathrm{~h}$; C) and D) $6 \mathrm{~h}$; E) and F) $48 \mathrm{~h}$.
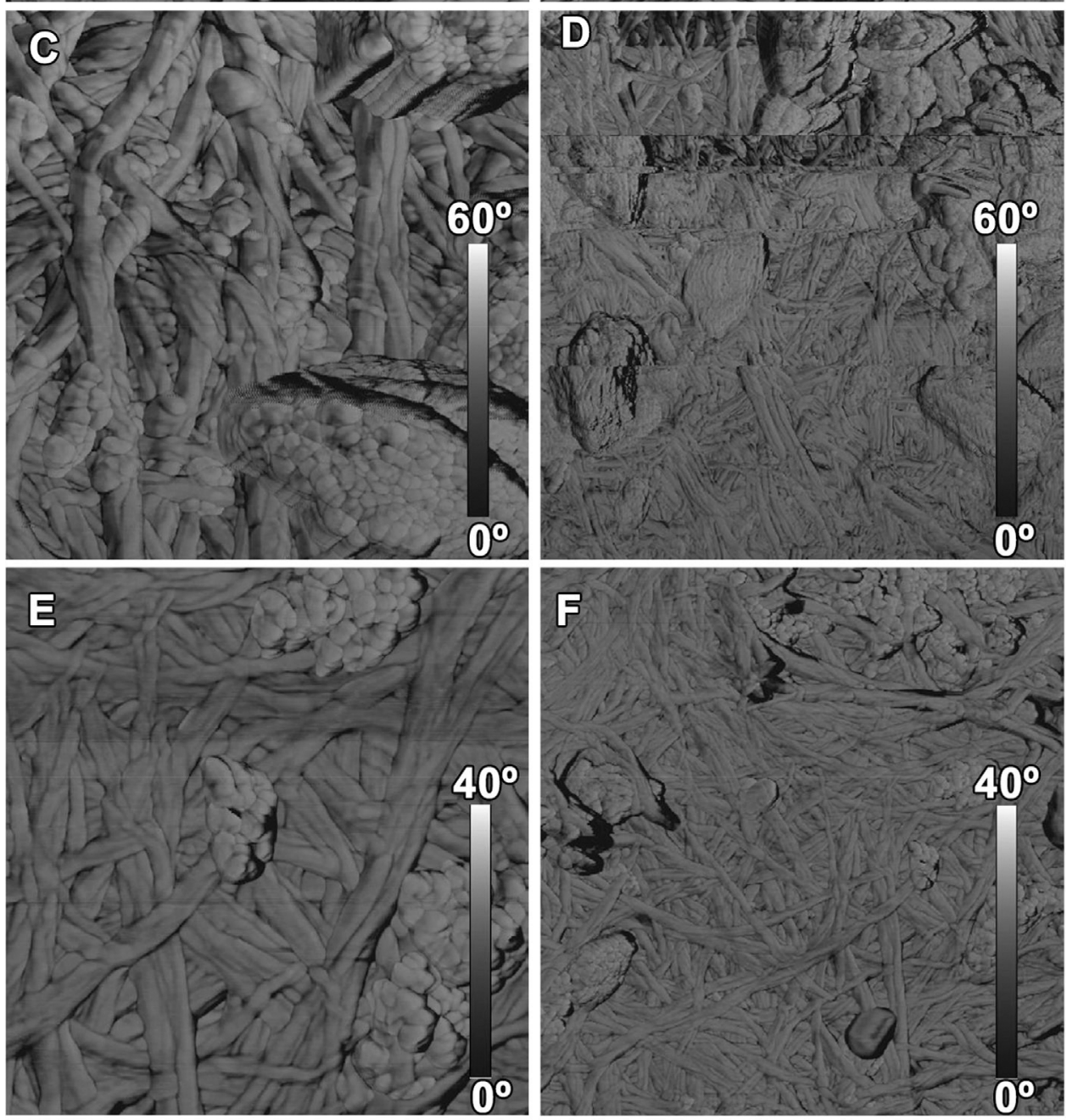

2) ח

hydrothermal carbonization (Li et al., 2012, Yao, Huo \& Jin, 2012). The formation of CuNPs under hydrothermal conditions in the presence of $\mathrm{BC}$ hydrogel can be achieved by both lateral reactions with byproducts of hydrothermal carbonization of $\mathrm{BC}$ as well as by undertaking reactions with active hydroxyl sites of BC fibers. Consequently, both pathway may leverage the synthesis of CuNPs that are finally trapped
50

under strongly interactions with the surface of the BC fibrils network. Those interactions can be easily identified by analysis of vibrational spectroscopy. 

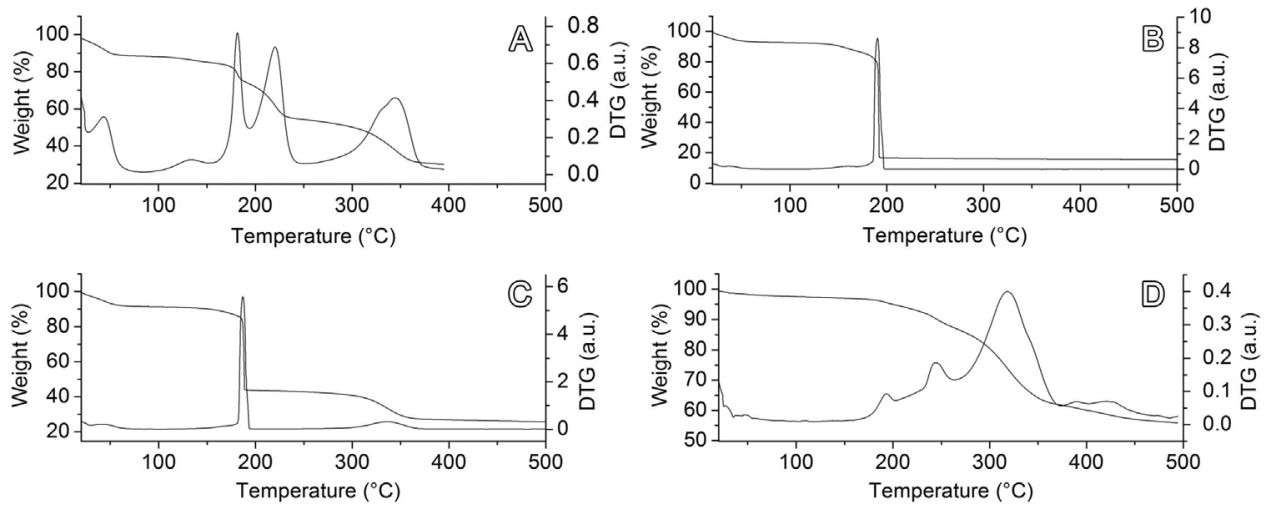

A

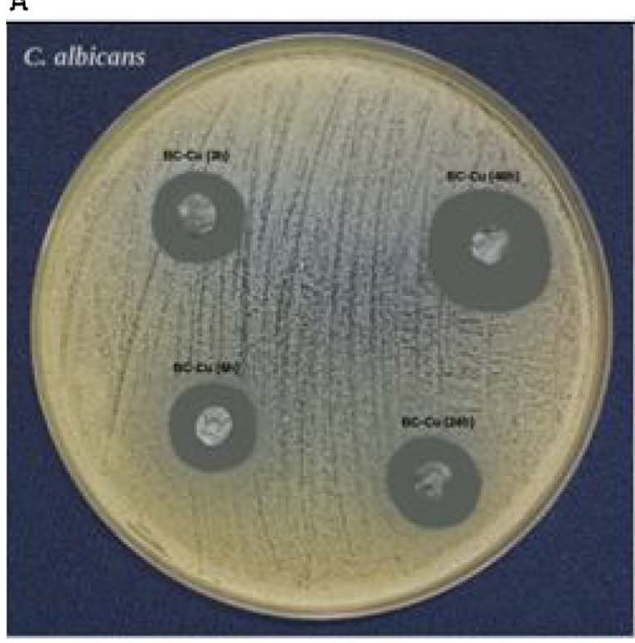

B

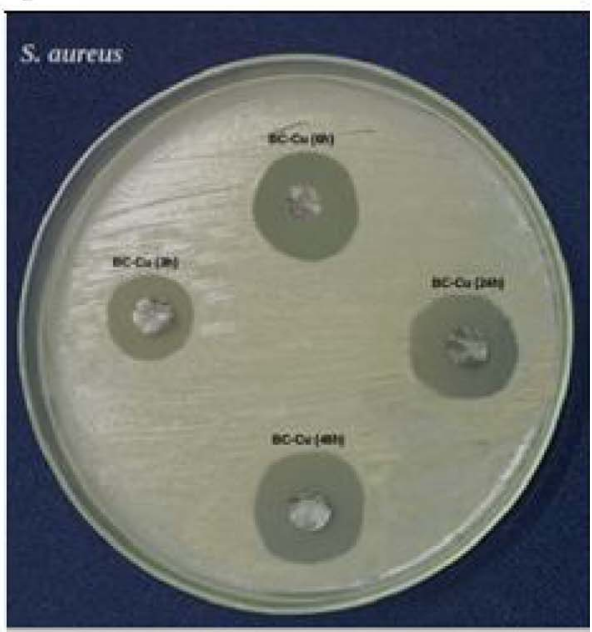

C

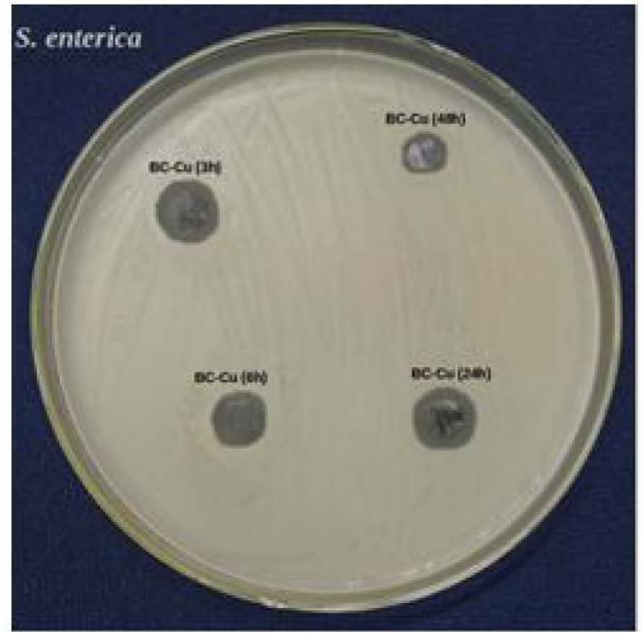

Fig. 6. TGA and DTG curves of BC-Cu nanocomposites synthetized by hydrothermal method $3,6,24$ and $48 \mathrm{~h}$ under heating rate of $10{ }^{\circ} \mathrm{C} / \mathrm{min}$ and oxidizing atmosphere (air).
Fig. 7. Zone of inhibition of bacterial growth by the action of BC-Cu ( $3 \mathrm{~h}, 6 \mathrm{~h}, 24 \mathrm{~h}$ and $48 \mathrm{~h})$. A) inhibition of yeast growth C. albicans; B) Growth inhibition of Gram-positive $S$. aureus; C) growth inhibition of Gram-negative $S$. enterica.
Table 1

Mean values of zones of inhibition relative to the different strains for the BC-Cu membranes, including disk diameter in $\mathrm{mm}$.

\begin{tabular}{llll}
\hline & \multicolumn{2}{l}{ Inhibition zone in $\mathrm{mm}(+0.1 \mathrm{~mm})$} \\
\cline { 2 - 4 } Time & C. albicans & S. aureus & S. enterica \\
\hline $3 \mathrm{~h}$ & 25.9 & 24.8 & 16.9 \\
$6 \mathrm{~h}$ & 24.7 & 30.0 & 14.8 \\
$24 \mathrm{~h}$ & 25.9 & 30.9 & 13.2 \\
$48 \mathrm{~h}$ & 33.7 & 30.5 & 12.5 \\
\hline
\end{tabular}

\subsection{Fourier transform infrared spectroscopy (FTIR)}

Fig. 2 shows the FTIR spectra of BC membrane and BC-Cu nanocomposites synthesized within 3,24 and $48 \mathrm{~h}$. The characteristic vibrational bands of $\mathrm{BC}$ membrane are: $3344 \mathrm{~cm}^{-1}$ stretch of $\mathrm{OH}$, $2898 \mathrm{~cm}^{-1}$ stretch CH (Tomé et al., 2010; Goh et al., 2012; Ciolacu, Ciolacu \& Popa, 2011, Santos et al., 2015) of alkanes and asymmetrical stretch of $\mathrm{CH}_{2}, 1650 \mathrm{~cm}^{-1}$ deformation of $\mathrm{OH}, 1429 \mathrm{~cm}^{-1}$ deformation $\mathrm{CH}_{2}, 1160 \mathrm{~cm}^{-1}$ stretch of $\mathrm{C}-\mathrm{O}-\mathrm{C}, 1054 \mathrm{~cm}^{-1}$ stretch $\mathrm{CO}$ and CC, 1031 and $983 \mathrm{~cm}^{-1}$ stretch $\mathrm{CO}, 1371-1280 \mathrm{~cm}^{-1}$ deformation of $\mathrm{CH}$, $1315 \mathrm{~cm}^{-1}$ deformation of $\mathrm{OH}$ on the plane (Santos et al., 2015; Goh 
et al., 2012; Ashori, Sheykhnazari, Tabarsa, Shakeri, \& Golalipour, 2012 Grube, Shvirksts, Denina, Ruklisa, \& Semjonovs, 2016).

The band at $3344 \mathrm{~cm}^{-1}$ in the BC-Cu nanocomposites shifts to lower wavenumbers for longer reaction times, which is an indicative of strong interactions between the $\mathrm{Cu}(\mathrm{II})$ ions and hydroxyls sites of BC fibrils. In addition, a band at $1646 \mathrm{~cm}^{-1}$ attributed to the out-of-plane deformation of $\mathrm{OH}$ groups of cellulose chains, appears in lower wavenumbers.

The crystallinity of cellulose can be estimated by measuring the ratio between i) 1372 and $2900 \mathrm{~cm}^{-1}$ or ii) 1430 and $893 \mathrm{~cm}^{-1}$ bands (Ciolacu et al., 2011). However, these bands (1372/2900 and 1430/ 893) were not identified in FTIR spectra of BC-Cu nanocomposites synthetized within $24 \mathrm{~h}$ or $48 \mathrm{~h}$.

It is worth to point out that the changes among FTIR spectra of pristine $\mathrm{BC}$ membrane and $\mathrm{BC}-\mathrm{Cu}$ nanocomposite can be noticed by the shifting of $2898 \mathrm{~cm}^{-1}$ band to lower wavenumbers followed by decreasing of relative intensity. This band is attributed to the stretching of $\mathrm{CH}_{2}$ and $\mathrm{CH}_{3}$ groups. The FTIR spectrum of $\mathrm{BC}-\mathrm{Cu}$ nanocomposite synthetized within $48 \mathrm{~h}$ displays three additional bands at $1629 \mathrm{~cm}^{-1}$, $1319 \mathrm{~cm}^{-1}$ and $1419 \mathrm{~cm}^{-1}$ which can be attributed to $-\mathrm{C}=\mathrm{O},-\mathrm{CH}_{2}-$ and $-\mathrm{CH}_{3}$ vibrational bands, respectively. Noteworthy, $\mathrm{BC}-\mathrm{Cu}$ nanocomposite synthetized $48 \mathrm{~h}$ shows typical bands of copper oxides. Specifically, this spectrum shows bands corresponding to 424, 499, 601 and $673 \mathrm{~cm}^{-1}$, all attributed to $\mathrm{Cu}-\mathrm{O}$ vibrations of copper oxide/hydroxide vibrational bands (Ethiraj \& Kang, 2012).

\subsection{X-ray diffractions (XRD)}

$\mathrm{X}$-ray diffractions of $\mathrm{BC}$ membrane and $\mathrm{BC}-\mathrm{Cu}$ nanocomposites are shown in Fig. 3. The XRD pattern of the BC membrane shows two typical intense peaks at 14.8 and $22.9^{\circ}$. These peaks can be attributed to the crystallographic plane of reflection (100) and (200), respectively (Santos et al., 2015; Zhang et al., 2010; Hu et al., 2010).

The diffraction peaks found for $\mathrm{BC}-\mathrm{Cu}$ nanocomposites are attributed to a mixture of $\mathrm{Cu}$ species: orthorhombic phase of $\mathrm{Cu}(\mathrm{OH})_{2}$ (JCPDS: \#80-0656), monocycle phase of $\mathrm{CuO}$ (according to Reference code: \#00-001-1117), the cubic phase of $\mathrm{Cu}_{2} \mathrm{O}$ and $\mathrm{Cu}$, (according to Reference code: 00-001-1142 and Reference code: \#00-001-1241, respectively). However, there are differences between the XRD of the pattern of the $\mathrm{BC}$ membrane and the $\mathrm{BC}-\mathrm{Cu}$ nanocomposites.

Further to the copper oxides, $\mathrm{Cu}(\mathrm{OH})_{2}$ phases were also observed in the composites, that corroborated with ortorrombic structure observed in SEM images (Fig. 5b-d). Another important feature is the peak thinning that reflects the best bundling.

\subsection{Scanning electron microscope (SEM)}

The morphology of BC membrane (Fig. 4a) is represented by long fibers with nanometric diameter, extending in a network of interwoven fibers. Fig. 5 shows the SEM images of pristine BC membrane and BC-Cu nanocomposites synthetized within 3, 24 and $48 \mathrm{~h}$, respectively. As the hydrogen interactions among $\mathrm{BC}$ fibers are weakened with the introduction of CuNPs, the BC-Cu nanocomposites become more compact. To further confirm the elemental composition of BC-Cu nanocomposites, energy dispersive spectroscopy (EDS) analysis was carried out.

The EDS results indicated the presence of carbon, nitrogen, oxygen and copper (results not shown here). The presence of oxygen suggested that the sample has a layer of oxide. However, the deposition mechanism of the copper is not totally explained, since the $\mathrm{Cu}(\mathrm{II})$ ions can be reduced in the solution. Once hydrolysis of $\mathrm{Cu}(\mathrm{II})$ ions occurs, $\mathrm{Cu}$ $(\mathrm{OH})_{2}$ and $\mathrm{Cu}_{\mathrm{x}} \mathrm{O}_{\mathrm{y}}$ deposit directly on the BC fibers surface.

The copper oxides formation mechanism on BC membranes is not fully understood, but probably involves a reaction with hydroxyl groups from the surface of BC fibrils and eventually with the reducing sugars and other products of the alkaline hydrolysis of cellulose (Yao, Hu \& Jin, 2012; Li et al., 2012). The copper reduction process in an alkaline medium in the hydrothermal synthesis must occur in the following steps: initially, there occurs an alkaline hydrolysis process (Bobleter, 1994). The alkaline medium facilitates the breaking of the 1-4 $\beta$-glycoside bonds of cellulose. The formation of copper oxide occurs by the release, in the hydrolysis process, of monosaccharides (glucose and others) and/or oligomers of reducing sugars. To obtain only metallic copper the temperature of the hydrothermal reaction has to be higher than $250^{\circ} \mathrm{C}$ (Li et al., 2012; Yao, Hu \& Jin, 2012; Bobleter, 1994).

\subsection{Atomic force microscopy (AFM)}

AFM phase images of BC-Cu nanocomposites synthetized 3, 6 and $24 \mathrm{~h}$ are shown in Fig. 5. Similarly, as from SEM results, one can easily concluded that $\mathrm{BC}-\mathrm{Cu}$ nanocomposites maintain the interconnected nanofibers network independently on hydrothermal synthesis time. The increase of the hydrothermal synthesis time led to more compact nanofiber network structure with clearly CuNPs nanoparticles on the surface of analyzed $\mathrm{BC}-\mathrm{Cu}$ nanocomposites. The increase of heating time provokes appearance of small domains positioned on the $\mathrm{BC}$ nanofibers, which correspond to formation of CuNPs. The size of these CuNPs varied between 25 and $35 \mathrm{~nm}$ in diameter. Moreover, as clearly shown in AFM images, CuNPs aggregates are obtained independently on heating time (Fig. 5a, c and e). Those aggregates consist of few individual CuNPs and are homogenously dispersed on the investigated surface of BC-Cu nanocomposites. The increase of heating time results in smother and more compact interconnected nanofibers network confirmed with a strong effect on the average roughness $\left(R_{a}\right)$ calculated from the AFM height images. The $R_{a}$ decreases with increase of heating time, being $172 \mathrm{~nm}$ after $3 \mathrm{~h}$ and $82 \mathrm{~nm}$ after $24 \mathrm{~h}$. This phenomenon can be strongly related to the presence of the CuNPs on the analyzed surface of BC-Cu nanocomposites.

\subsection{Thermogravimetric analysis (TGA)}

The thermal stability of the BC membrane and BC-Cu nanocomposites was studied using TGA in oxidizing atmosphere. The BC membrane curve showed two weight loss steps as shown in Fig. 6 . The first one at the temperature ranging from $50^{\circ} \mathrm{C}$ to $150{ }^{\circ} \mathrm{C}$, which was attributed to loss of volatiles and to the dehydration of the cellulose membrane (Barud et al., 2007; Cai, Kimura, Wada \& Kuga, 2009; Hu et al., 2010; Chen et al., 2013). The second step, between the temperatures of $280-375{ }^{\circ} \mathrm{C}$, is related with the burning of BC producing carbon dioxide, water and carbon residues (Chen et al., 2013; Rambo, Recouvreux, Carminatti, Pitlovanciv, Antonio , \& Porto, 2008). The residues that are not consumed correspond roughly to $17 \%$.

For the $\mathrm{BC}-\mathrm{Cu}$ nanocomposites synthetized at 3,6, 24 and $48 \mathrm{~h}$, Fig. 6 , it is possible to observe that there was no pattern in the weight loss of the cellulose with copper. The BC-Cu nanocomposites synthetized $3 \mathrm{~h}$ shows similar degradation steps to those synthetized $48 \mathrm{~h}$. On the other hand, the BC-Cu nanocomposites synthetized within 6 and $24 \mathrm{~h}$ showed also two steps, and a marked loss of weight in a narrow temperature range. The residues of the $\mathrm{BC}-\mathrm{Cu}$ nanocomposites increased if compared with the residues of the $\mathrm{BC}$ membrane. This could be attributed to the presence of copper that cannot be volatilized in the assessed temperature range. For BC-Cu nanocomposites, the temperature ranges of the thermal steps had lower weight loss values than the $\mathrm{BC}$ membrane. Possible explanations are a) the presence of copper can catalyze thermal degradation reactions leading to weight loss in lower temperatures; b) the copper oxide can react, suffering reduction in the presence of heated cellulose and subsequent oxidation at higher temperatures.

\subsection{Study of the antimicrobial activity}

One of the main uses of the $\mathrm{BC}$ membrane is as bandage in the 
healing process of wounds. However, pristine $\mathrm{BC}$ membrane itself do no display antimicrobial activity to prevent infection (Maneerung et al., 2008). Due to the high surface area and the great number of pores in its structure BC membrane could be acting as a matrix to incorporate antimicrobial agents like copper and copper oxides.

For pristine $\mathrm{BC}$ membrane, no antimicrobial activity was shown. This is in concordance with the literature (Maneerung et al., 2008; Janpetch, Saitb \& Rujiravaniti, 2016). Consequently, only CuNPs nanoparticles may show antimicrobial response in BC-Cu nanocomposites. From antimicrobial test was also observed that even after a certain time of exposure, the color of the BC-Cu nanocomposites keeps unchanged, which indicates resistance against oxidation. The antibacterial activity of BC-Cu nanocomposites was evaluated employing Gram-positive bacterial specie (S. aureus) and Gram-negative (E. coli, S. enterica) and yeast $C$. albicans. The disk diffusion test (CLSI, 2016) was performed. The diameter of the inhibition zone reflects the magnitude of the susceptibility of a micro-organism. Disk diffusion assays showed the inhibitory activity of the different BC-Cu nanocomposites against all selected microorganisms strains. The Fig. 7 illustrates the inhibition zone of growth to the Different types for the BC-Cu membranes on yeast ( $C$. albicans) and the bacteria Gram-positive ( $S$. aureus) and Gram negative ( $S$. enterica). According this assays the hydrothermal processing time has any significance on antimicrobial effect. The results presented in Table 1 show the measurement inhibition zone of the microorganisms growth (in millimetres). In fact, $\mathrm{Cu}(\mathrm{II})$ ions or CuNPs may be acting on the cell through different mechanisms. Different studies report that the metal can act by breaking the membrane, blocking the biochemical route, forming complexes with proteins and even causing damage to DNA (Bagchi et al., 2012; Warnes \& Keevil, 2011; Ruparelia, Chatterjee, Duttagupta, \& Mukherji, 2008).

\section{Conclusions}

The hydrothermal process was used to fabricate $\mathrm{BC}-\mathrm{Cu}$ nanocomposites with different hydrothermal synthesis time leading to $\mathrm{BC}$ based nanocomposites with different copper content. The copper oxide deposition mechanism on the surface of the BC membranes involved alkaline hydrolysis and subsequent reduction reactions. The presence of the of CuNPs on BC-Cu nanocomposites was successfully confirmed by spectroscopic, morphological and thermal characterizations. The results of the disk diffusion test of the different BC-Cu nanocomposites showed significate antimicrobial activity in vitro against all tested microorganisms. The results suggest the potential of BC-Cu nanocomposites to be use as dressing in contaminated wounds.

\section{Acknowledgements}

W. R. Lustri thanks to the Fundacão de Amparo à Pesquisa do Estado de São Paulo (FAPESP) for the Grant n. 2015/ 09833-0. R. R. Silva thanks to the Fundacão de Amparo à Pesquisa do Estado de São Paulo (FAPESP) for the Grant No. 2016/06612-6.

\section{References}

Andrade, F. K., Costa, R., Domingues, L., Soares, R., \& Gama, M. (2010). Improving bacterial cellulose for blood vessel replacement: functionalization with a chimeric protein containing a cellulose-binding module and an adhesion peptide. Acta Biomaterialia, 6(10), 4034-4041.

Ashori, A., Sheykhnazari, S., Tabarsa, T., Shakeri, A., \& Golalipour, M. (2012). Bacterial cellulose/silica nanocomposites: Preparation and characterization. Carbohydrate Polymers, 90(1), 413-418.

Bagchi, B., Dey, S., Bhandary, S., Das, S., Bhattachary, A., Basu, R., et al. (2012). Antimicrobial efficacy and biocompatibility study of copper nanoparticle adsorbedmullite aggregates. Materials Science and Engineering C, 32(7), 1897-1905.

Barud, H. S., Ribeiro, C. A., Crespi, M. S., Martines, M. A. U., Dexpert-ghys, J., Marques, R. F. C., et al. (2007). Thermal haracterization of bacterial cellulose-phosphate composite membranes. Journal of Thermal Analysis and Calorimetry, 87(3), 815-818.

Barud, H. S., Regiani, T., Marques, R. F. C., Lustri, W. R., Messaddeq, Y., \& Ribeiro, S. J. L. (2011). Antimicrobial bacterial cellulose-silver nanoparticles composite membranes.
Journal of Nanomaterials, 2011.

Barud, H. S., Ribeiro, S. J. L., Carone, C. L. P., Ligabue, R., Einloft, S. P., Queiroz, V. S., et al. (2013). Optically transparent membrane based on bacterial cellulose/polycaprolactone. Polímeros, 23(1), 135-138.

Barud, H. G. O., Silva, R. R., Barud, H. S., Tercjak, A., Gutierrez, J., Lustri, W. R., et al. (2016). A multipurpose natural and renewable polymer in medical applications: Bacterial celulose. Carbohydrate Polymers, 153, 406-420.

Bobleter, O. (1994). Hydrothermal degradation of polymers derived from plants. Progress Polymer Science, 19, 797-841.

Bodin, A., Bharadwaj, S., Wu, S., Gatenholm, P., Atala, A., \& Zhang, Y. (2010). Tissue-engineered conduit using urine-derived stem cells seeded bacterial cellulose polymer in urinary reconstruction and diversion. Biomaterials, 31(34), 8889-8901.

CLSI (2016). Performance standards for antimicrobial susceptibility testing (26th ed.). Wayne, PA: Clinical and Laboratory Standards Institute [CLSI supplement M100S].

Cady, N. C., Behnke, J. L., \& Strickland, A. D. (2011). Copper-based nanostructured coatings on natural cellulose: nanocomposites exhibiting rapid and efficient in- hibition of a multi-drug resistant wound pathogen, A. baumannii, and mammalian cell biocompatibility In vitro. Advanced Functional Materials, 21(13), 2506-2514.

Cai, J., Kimura, S., Wada, M., \& Kuga, S. (2009). Nanoporous cellulose as metal nanoparticles support. Biomacromolecules, 10(1), 87-94.

Castro, C., Cleenwerck, I., Trcek, J., Zuluaga, R., Vos, P. D., Caro, G., et al. (2013). Gluconacetobacter medellinensis sp. nov., cellulose- and non-cellulose-producing acetic acid bacteria isolated from vinegar. International Journal of Systematic and Evolutionary Microbiology, 63(3), 1119-1125.

Cavka, A., Guo, X., Tang, S., Winestrand, S., Jönsson, L. J., \& Hong, F. (2013). Production of bacterial cellulose and enzyme from waste fiber sludge. Biotechnology for Biofuels, 6, 25.

Chen, S., Zhou, B., Hu, W., Zhang, W., Yin, N., \& Wang, H. (2013). Polyol mediated synthesis of $\mathrm{ZnO}$ nanoparticles templated by bacterial cellulose. Carbohydrate Polymers, 92(2), 1953-1959.

Ciolacu, D., Ciolacu, F., \& Popa, V. I. (2011). Amorphous cellulose - structure and characterization? Cellulose Chemistry and Technology, 45(1-2), 13-21.

Czaja, W., Romanovicz, D., \& Brown, R. M. (2004). Structural investigations of microbial cellulose produced in stationary and agitated culture. Cellulose, 11(3), 403-411.

Czaja, W., Krystynowicz, A., Bielecki, S., \& Brown, J. R. R. M. (2006). Microbial cellulosethe natural power to heal wounds. Biomaterials, 27(2), 145-151.

Domini, Í. A. N., Salvi, D. T. B., Fukumoto, F. K., Lustri, W. R., Barud, H. S., Marchetto, R., et al. (2010). Biossíntese e recentes avanços na produção de celulose bacteriana. Eclética Química, 35(4), 165-178.

Esa, F., Tasirin, S. M., \& Rahman, N. A. (2014). Overview of bacterial cellulose production and application. Agriculture and Agricultural Science Procedia, 2, 113-119.

Ethiraj, A. S., \& Kang, D. J. (2012). Synthesis and characterization of $\mathrm{CuO}$ nanowires by a simple wet chemical method. Nanoscale Research Letters, 7, 70.

Feng, S., \& Xu, R. (2001). New Materials in Hydrothermal Synthesis. Accounts of Chemical Research, 34(3), 239-247.

Fu, L., Zhang, J., \& Yang, G. (2013). Present status and applications of bacterial cellulosebased materialsfor skin tissue repair. Carbohydrate Polymers, 92(2), 1432-1442.

Gao, C., Wan, Y., Yang, C., Dai, K., Tang, T., Luo, H., et al. (2011). Preparation and characterization of bacterial cellulose sponge with hierarchical pore structure as tissue engineering scaffold? Journal of Porous Materials, 18(2), 139-145.

Goh, W. N., Rosma, A., Kaur, B., Fazilah, A., Karim, A. A., \& Bhat, R. (2012). Microstructure and physical properties of microbial celluloseproduced during fermentation of black tea broth(Kombucha). II. International Food Research Journal, 19(1), 153-158.

Gould, S. W. J., Fielder, M. D., Kelly, A. F., Morgan, M., Kenny, J., \& Naughton, D. P. (2009). The antimicrobial properties of copper surfaces against a range of important nosocomial pathogens. Annals of Microbiology, 59(1), 151-156.

Grube, M., Shvirksts, K., Denina, I., Ruklisa, M., \& Semjonovs, P. (2016). Fourier-transform infrared spectroscopic analyses of cellulose from different bacterial cultivations using microspectroscopy and a high-throughput screening device. Vibrational Spectroscopy, 84, 53-57.

Hu, W., Chen, S., Zhou, B., \& Wang, H. (2010). Facile synthesis of ZnO nanoparticles based on bacterial cellulose. Materials Science and Engineering B, 170, 88-92.

Iguchi, M., Yamanaka, S., \& Budhino, A. (2000). Bacterial cellulose - A masterpiece of nature's arts. Journal of Materials Science, 35(2), 261-270.

Janpetch, N., Saito, N., \& Rujiravanit, R. (2016). Fabrication of bacterial cellulose-ZnO composite via solution plasmaprocess for antibacterial applications. Carbohydrate Polymers, 148, 335-344.

Jiazhi, Y., Xiaoli, L., Liyong, H., \& Dongping, S. (2013). Antibacterial properties of novel bacterial cellulose nanofiber containing silver nanoparticles? Chinese Journal of Chemical Engineering, 21(12), 1419-1424.

Jipa, I. M., Dobre, L., Stroescu, M., Stoica-Guzun, A., Jinga, S., \& Dobre, T. (2012). Preparation and characterization of bacterial cellulose-poly(vinyl alcohol) films with antimicrobial properties. Materials Letters, 66, 125-127.

Keshk, S. M. A. S. (2014). Vitamin C enhances bacterial cellulose production in Gluconacetobacter xylinus. Carbohydrate Polymers, 99, 98-100.

Kiziltas, E. E., Kiziltas, A., Blumentritt, M., \& Gardner, D. J. (2015). Biosynthesis of bacterial cellulose in the presence of different nanoparticles to create novel hybrid materials. Carbohydrate Polymers, 129, 148-155.

Kowalska-Ludwicka, K., Cala, J., Grobelski, B., Sygut, D., Jesionek-Kupnicka, D., Kolodziejczyk, M., et al. (2013). Modified bacterial cellulose tubes for regeneration of damaged peripheral nerves. Archives of Medical Science, 9(3), 527-534.

Li, Q., Yao, G., Zeng, X., Jing, Z., Huo, Z., \& Jin, F. (2012). Facile and green production of $\mathrm{Cu}$ from $\mathrm{CuO}$ using cellulose under hydrothermal conditions. Industrial \& Engineering Chemistry Research, 51(7), 3129-3136.

Lin, N., \& Dufresne, A. (2014). Nanocellulose in biomedicine: Current status and future 
Prospect. European Polymer Journal, 59, 302-325.

Lin, S. P., Calvar, I. L., Catchmark, J. M., Liu, J. R., Demirci, A., \& Cheng, K. C. (2013). Biosynthesis, production and applications of bacterial cellulose. Cellulose, 20(5), 2191-2219.

Liu, Z., \& Bando, Y. (2003). A novel method for preparing copper nanorods and nanowires. Advanced Materials, 15(4), 303-305.

Lopes, J. L., Machado, J. M., Castanheira, L., Granja, P. L., Gama, F. M., Dourado, F., et al. (2011). Friction and wear behaviour of bacterial cellulose against articular cartilage. Wear, 271(9-10), 2328-2333.

Maneerung, T., Tokura, S., \& Rujiravanit, R. (2008). Impregnation of silver nanoparticles into bacterial cellulose for antimicrobial wound dressing. Carbohydrate Polymers, 72, 43-51.

Martínez, H., Brackmann, C., Enejder, A., \& Gatenholm, P. (2012). Mechanical stimula tion of fibroblasts in micro-channeled bacterial cellulose scaffolds enhances production of oriented collagen fibers. Journal of Biomedical Materials Research Part A, 100(4), 948-957.

Nishiyama, Y. (2009). Structure and properties of the cellulose microfibril. Journal of Wood Science. 55(4), 241-249.

Ógorman, J., \& Humphreys, H. (2012). Application of copper to prevent and control infection. Where are we now? Journal of Hospital Infection, 81(4), 217-223.

Pineda, L. D. C., Mesa, L. A. C., \& Riasco, C. A. M. (2012). Técnicas de fermentación y aplicaciones de la celulosa bacteriana: una revisión. Ingeniería y Ciencia, 8(16), 307-335.

Pinto, R. J. B., Marques, P. A. A. P., Martins, M. A., Neto, C. P., \& Trindade, T. (2007). Electrostatic assembly and growth of gold nanoparticles in cellulosic fibres. Journal of Colloid and Interface Science, 312(2), 506-512.

Pinto, R. J. B., Neves, M. C., Neto, C. P., \& Trindade, T. (2012). Growth and chemical stability of copper nanostructures on cellulosic fibers. European Journal of Inorganic Chemistry, 2012(31), 5043-5049.

Rambo, C., Recouvreux, D., Carminatti, C., Pitlovanciv, A., Antonio, R., \& Porto, L. (2008). Template assisted synthesis of porous nanofibrous cellulose membranes for tissue engineering. Materials Science \& Engineering C-Biomimetic and Supramolecular Systems, 28(4), 549-554.

Rajwade, J. M., Paknikar, K. M., \& Kumbhar, J. V. (2015). Applications of bacterial cellulose and its composites in biomedicine. Applied Microbiology and Biotechnology, 99(6), 2491-2511.

Rueff, J., Poienar, M., Guesdon, A., Martin, C., Maignan, A., \& Jaffrès, P. (2016). Hydrothermal synthesis for new multifunctional materials: A few examples of phosphates and phosphonate-based hybrid materials. Journal of Solid State Chemistry, 236, 236-245.

Ruparelia, J. P., Chatterjee, A. K., Duttagupta, S. P., \& Mukherji, S. (2008). Strain specificity in antimicrobial activity of silver and copper nanoparticles. Acta Biomaterialia, 4, 707-716.

Santos, S. M., Carbajo, J. M., Quintana, E., Ibarra, D., Gomez, N., Ladero, M., et al. (2015). Characterization of purified bacterial cellulose focused on its use on paper restoration. Carbohydrate Polymers, 116, 173-181.

Shi, W., Song, S., \& Zhang, H. (2013). Hydrothermal synthetic strategies of inorganic semiconducting nanostructures. Chemical Society Reviews, 42(13), 5714-5743.

Song, J., Birbach, N. L., \& Hinestroza, J. P. (2012). Deposition of silver nanoparticles on cellulosic fibers via stabilization of carboxymethyl groups. Cellulose, 19(2), 411-424.

Svensson, A., Nicklasson, E., Harrah, T., Panilaitis, B., Kaplan, D. L., Brittberg, M., et al.
(2005). Bacterial cellulose as a potential scaffold for tissue engineering of cartilage. Biomaterials, 26(4), 419-431.

Thakur, V. K. E., \& Voicu, S. I. (2016). Recent advances in cellulose and chitosan based membranes for water purification: A concise review. Carbohydrate Polymers, 146, $148-165$.

Tomé, L. C., Brandão, L., Mendes, A. M., Silvestre, A. J. D., Neto, C. P., Gandini, A., et al. (2010). Preparation and characterization of bacterial cellulose membranes with tailored surface and barrier properties. Cellulose, 17(6), 1203-1211.

Trovatti, E., Fernandes, S. C. M., Rubatat, L., Freire, C. S. R., Silvestre, A. J. D., \& Neto, C. P. (2012). Sustainable nanocomposite films based on bacterial celulose and pullulan. Cellulose, 19(3), 729-737.

Tsouko, E., Kourmentza, C., Ladakis, D., Kopsahelis, N., Mandala, I., Papanikolaou, S. et al. (2015). Bacterial cellulose production from industrial waste and by-product streams. International Journal of Molecular Sciences, 16, 14832-14849.

Umer, A., Naveed, S., Ramzan, N., Rafique, M. S., \& Imran, M. (2014). A green method for the synthesis of Copper Nanoparticles using L-ascorbic acid? Revista Matéria, 19(3), 197-203.

Vainio, U., Pirkkalainen, K., Kisko, K., Goerigk, G., Kotelnikova, N. E., \& Serimaa, R. (2007). Copper and copper oxide nanoparticles in a cellulose support studied using anomalous small-angle X-ray scattering. The European Physical Journal D, 42(1), 93-101.

Wang, W., Zhang, T., Zhang, D., Li, H., Ma, Y., Qi, L., et al. (2011). Amperometric hydrogen peroxide biosensor based on the immobilization of heme proteins on gold nanoparticles-bacteria cellulose nanofibers nanocomposite. Talanta, 84, 71-77.

Wang, S., Lu, A., \& Zhang, L. (2016). Recent advances in regenerated cellulose materials. Progress in Polymer Science, 53, 169-206.

Warnes, S. L., \& Keevil, C. W. (2011). Mechanism of copper surface toxicity in vancomycin-resistant enterococci following wet or dry surface contact. Applied and Environmental Microbiology, 77(17), 6049-6059.

Wei, B., Yanga, G., \& Honga, F. (2011). Preparation and evaluation of a kind of bacterial cellulose dry films with antibacterial propert. Carbohydrate Polymers, 84, 533-538.

Woehl, M. A., Canestraro, C. D., Mikowski, A., Seerakowski, M. R., Ramos, L. P., \& Wypych, F. (2010). Bionanocomposites of thermoplastic starch reinforced with bacterial cellulose nanofibres: effect of enzymatic treatment on mechanical properties. Carbohydrate Polymers, 80, 866-873.

Yang, G., Xie, J., Hong, F., Cao, Z., \& Yang, X. (2012). Antimicrobial activity of silver nanoparticle impregnated bacterial cellulose membrane: Effect of fermentation carbon sources of bacterial cellulose. Carbohydrate Polymers, 87, 839-845.

Yang, J., Xiaoli, L., Liyong, H., \& Dongping, S. (2013). Antibacterial properties of novel bacterial cellulose NanofiberContaining silver nanoparticles. Chinese Journal of Chemical Engineering, 21(12), 1419-1424.

Yang, J. X., Chen, S. Y., \& Wang, H. P. (2014). Facile preparation of gradient structure bacterial cellulose using potato starch. Materials Science Forum, 789, 95-99.

Yao, G., Huo, Z., \& Jin, F. (2011). Direct reduction of copper oxide into copper under hydrothermal conditions. Research on Chemical Intermediates, 37, 351-358.

Zhang, B. T., Wang, W., Zhang, D., Zhang, X., Ma, Y., Zhou, Y., et al. (2010). Biotemplated synthesis of gold nanoparticle-bacteria cellulose nanofiber nanocomposites and their application in biosensing. Advanced Functional Materials, 20, 1152-1160.

Zhu, L., Elguindi, J., Rensing, C., \& Ravishankar, S. (2012). Antimicrobial activity of different copper alloy surfaces against copper resistant and sensitive Salmonella entérica. Food Microbiology, 30, 303-310. 